International Journal of Heritage, Tourism and Hospitality Vol. (11), No. (4), October, 2017

By: Faculty of Tourism and Hotels, Fayoum University

A Special Issue on 'Entrepreneurship of Tourism, Hospitality and Heritage in Egypt': A Vision for Sustainable Development'

The $1^{\text {st }}$ International Conference Organized by Faculty of Tourism and Hotel Management, Pharos University, Alexandria, Egypt on $24^{\text {th }}-27^{\text {th }}$ October 2017

\title{
The Collection of Carl Wilhelm Von Gerber Unknown Heritage
}

Islam Asem Abdelkariem

The High Institute of Tourism, Hotels and Monuments Restoration of Abokir

\begin{abstract}
Carl Wilhelm von Gerber (1883-1959), the late General Consul of Sweden in Alexandria, was the most famous Swedish diplomat in Alexandria in the Twentieth Century. He played a significant role during WWI and WWII besides his economic activities between the Scandinavian countries and Egypt. The Swedish institute Alexandria (SwedAlex), which occupies nowadays his mansion, was built in 1925. it owns an important collection of the belongings of C.W. von Gerber. This paper aims at making the documentation of the collection of the belongings through his rich biography that could be obtained from the archive of the institute and publishing this important collection for the first time. this will shed light on the unknown part of the heritage of Alexandria during that period and lead to show the possibilities of converting the collection's showcase in SwedAlex to a private museum to enrich the heritage tourism in Alexandria.
\end{abstract}

Keywords: Alexandria, Medal, Order, von Gerber, Heritage Tourism, Swedish institute .

\section{Introduction}

This research constitutes a relatively new area which has emerged from the modern history of Alexandria that has a cosmopolitan aspect. In the Swedish institute Alexandria (SwedAlex) there is a showcase that contains the belongings of the late General Consul of Sweden in Alexandria, Carl Wilhelm von Gerber (1883-1959). This showcase lacks information of each piece and it gives few details about the life of von Gerber to the visitors. To this date, there is no study that examined this collection to document it. Only one study was made to search for the cause of death of von Gerber by tracing the stories of the old neighbors and reading the documents related to von Gerber in the archive of the institute. Unfortunately, the study is kept in the institute without a translation as it was written in Swedish (Hjarre and Signeul, n.d.).

However, a few pieces of the collection have been dealt with indirectly in few studies concentrated on the orders and decorations (ابر اهيم 1998)؛ اللقاني،2005؛رجب، 2013), but the majority of the collection will be studied for the first time in this paper. it will shed light on a rare pieces that have not any similarities in any museum in Egypt. The importance of this study will be in the documentation of the whole collection for the first time and relating it with the biography of von Gerber that will give an integrated view of the Alexandrian society in the first-mid of the Twentieth Century.

The objective of this study is to demonstrate the feasibility of forming a new museum for the collection of von Gerber that could enrich the heritage tourism in Alexandria and to document and publish the biography and the collection of von Gerber.

\section{C.W. von Gerber Biography}

Carl Wilhelm von Gerber (Pl. 1) was born on $12^{\text {th }}$ May 1883 in Sölvesborg, south of Sweden, where he grew up in a German Origin Family. his great grandfather Carl Von Gerber(17721864) was the Supreme Lieutenant in Stralsund and Rugen in Germany and his grandfather Wilhelm von Gerber (1812-1881) was a cavalry Captain in Swedish armed forces(Von Gerber, 1954). His father Axel Wilhelm (1849-1911) was born in Skottlandshus village and he owned some properties in Sölvesborg and worked as a merchant. His mother is Ida Gustava Nilsson (1882-1928) and he only had one brother whose name is Tage Erhard, born on $8^{\text {th }}$ February 1885(Von Gerber, 1954). 
On $10^{\text {th }}$ June 1902 he finished the baccalaureate stage by passing the Studentexamen, which is the university admission examination in Sweden, in Kristianstad School, which lies some 31 kilometers away from his birth city. In 1903 he succeeded in obtaining a diploma from Gothenburg Business Institute and started work in trade in Germany (Burling, 1956).

His work in Germany was the starting point of his story with Egypt, as he was working for an agency exporting lumber to Egypt. It is apparently quite clear that von Gerber studied the lumber trade size to Egypt. Von Gerber stated a report to Stockholm Kommerskolleguim published in The Princeton Union newspaper, saying "Sweden's Exports to Egypt consist chiefly of lumber and all this business is at present taken care of by foreign firms in Egypt, who are doing so well that are employing their own agents in Sweden to place their orders. This business, instead of passing into the hands of Swedish-Egyptian firms, who are handling the lumber business of Egypt and import about 12,000,000 crowns worth of it from Sweden every year" (News of Scandinavia, 1908, p.3).

Obviously, his opinion in how the German taking over the lumber trade reflects why he chose Egypt to start his professional life and proves how he was right to lead in this kind of trade in Egypt. So, on $27^{\text {th }}$ May 1907, von Gerber decided to start a new life in Egypt, when he came on board of "M/S Andros" of "Deutsche Levante-Linie" to reside in Alexandria (Hjarre and Signeul, n.d.).

By 1908, von Gerber had founded new business besides lumber trade such as being an agent for Primus cook stove, which was the world's first soot-free kerosene stove(125 years of primus n.d.) and gas light stockings in North Africa, from which he received a high regular income that helped him to build Wardian sawmill. This way, he made his own wealth and reputation that let him being appointed the Swedish vice-consul in Alexandria in 1921. Then he was promoted to consul in 1925 till he became a general consul from 1939 to 1951(Von Gerber, 1954; International Council on Archives, 1981) and during the WWII(1939-1945) he politically represented Denmark, Norway, Germany, Hungry and Finland in Alexandria.(Von Gerber, 1954). It is mentioned that until November 1942 the German Swastika flag was hoisted together with the Swedish flag on von Gerber mansion that hosted the Swedish consulate. Also, Hitler's book "Mein Kamp" was distributed to visitors of the Consulate (Hjarre and Signeul, n.d.).

Von Gerber managed a huge business in various fields such as agricultural and industrial Machinery, Railway equipment, negotiation and Commissionaires, paper, Water pumps and lumbers from his Cairo office and store, besides the work of importing and selling Construction materials and being a marine agent and broker in Alexandria (L'Annuaire Égyptien, 1913 ; L'Annuaire Égyptien, 1941). Moreover, company Stamp of the so-called "Society of Home Supply" in Cairo (Pl. 2) was found in his collection.

On the other hand, von Gerber was fond of history and archeology as he was a member of the Swedish Cyprus expedition of archaeology 1927-1931(Gjerstad et al.1934) and a member of the first archeological society in Egypt; the so-called "the Archaeological Society of Alexandria". Not only that, but he was elected as vice-president of this society in 1946 and he became the president of the society in 1954 till his death (el-abbadi, 2003).

His role in the Archaeological Society of Alexandria exceeded the administrative role to a historian with two scientific papers. in French, published in the Bulletins of Society No. 36 and 41, the first was entitled "Une visite à Alexandrie en 1829" was published 1944 (Gerber, 1944) and the other was published in 1956 and was entitled "Voyages en Égypte de quelques Orientalistes Suédois" (Registration No.: 97182, 2017). 


\section{Results}

According to the above-mentioned biography of von Gerber that proves the important political, economic and cultural role he played in Alexandria, and by examining his collection shown in the institute, the researcher concentrated on the medals, orders and badges of von Gerber since they have the greatest historical value among his collection. The next lines will demonstrate the result of studying the belongings of von Gerber with the description and documentation.

\section{Two Commemorative Medals of the Egyptian Trotter Competition of Dressage.}

Two rounded gilded silver medals with the signature of A. Erdmann close to the rim of the obverse side of the medals. So that both medals could be considered from a very rare example of the French medalist Louis Auguste Albert Erdmann (1879-1914), who has his collection shown in Musée d'Orsay in Paris (Louis Auguste Albert Erdmann, 2006).

The obverse side of the medals features a rearing horse with its tamer who is holding the horse bridle in his right hand trying to control it, and tamer's stick in the other hand, meanwhile the Greek goddess Nike putting the crown of laurel on the head of the tamer as a winner, with a background of three raving horses. The appearance of Nike here is very significant as a goddess of victory that was highly honored by the Romans under the name of Victoria. She appears here with her large and graceful wings, flowing drapery which is fastened on the right shoulder and in her right hand holds a palm-branch and in the left always holds a crown of laurel (Berens, 1886).

Both medals are identical in the obverse side (Pl. 3); but on the reverse side, one has a branch of laurel with the goddess Nike around a circular central medallion inscribed in French "Trotter Egyptien, Concours Hippique du 3 Juin 1905, Medaille Commemorative, Alexandrie" which means "Egyptian Trotter, Horse Show of $3^{\text {rd }}$ June 1905, Medal Commemorative, Alexandria" (Pl. 4), this side has the signature of famous French medalist Adolphe Rivet, whose collection shown in the Metropolitan museum (Collection of Adolphe Rivet, 2018) and this design especially was repeated in other medal (Noran, n.d) of him which indicates that was not an exclusive design for this medal.

The other medal (Pl. 4) has the same inscriptions with a difference in the date "12 $2^{\text {th }}$ May 1906 " mentioned in the circular central medallion and oak branches with an angel holding a laurel branch in his hand designed the edge around.

\section{Commemorative medal of the Stockholm Olympic Games (Pl. 5).}

This medal is considered one of 6000 medals made of oxidized and ordinary pewter that was rewarded to all the staff of the offices of the Swedish Olympic Committee, all competitors who started in any event and to all persons, "Swedish or foreigne", who had labored and helped in the success of Stockholm games(Bergvall, ed., 1913).

The obverse of the medal had to be the same as that of the commemorative medal of the London games 1908 that was designed by Bertram Mackennal. So that it took the same design that features a Greek chariot drawn by four horses, in which the charioteer and a judge ready to present the palm of victory to the triumphant athlete. The reverse side was designed by E. Lindberg, which shows the Greek god Zeus sitting in a chair on Ionic column, holding in his left hand a scepter and in the right hand a figure ot the victory Greek goddess Nike. In the background it shows the outlines of the royal palace of Stockholm, which of Helgeandsholmen Island and the façade of Riksdag House(Bergvall, ed., 1913) and in two rows over the head of Zeus is written in Swedish "TILL MINNE AF OLYMPISKA SPELEN, STOCKHOLM 1912" which means "In memory of the Olympic Games, Stockholm 1912".

Two Prussian Red Cross Medals (Pl. 6). 
Red Cross Medal was founded by Wilhelm II in 1898 as a Prussian medal of honor for all those who were especially active on behalf of the Red Cross and for those who have made a name for themselves through many years of activity or outstanding actions for the Red Cross. It was awarded in three classes :bronze, silver and Gold (Military intelligence, 1945).

C.W. von Gerber awarded two medals of the third Class, which takes a circular shape, but one of them is made of bronze and suspended from a red ribbon with white and black stripes which was the original material and shape of the medal before the change that was caused by WWI, so it can be dated between 1898 to1914 (Red Cross medal 3rd class 1898 in bronze, 2018). The other medal, due to the WWI economic circumstances, was made of fine zinc and it was awarded by the end of the war from 1917 and until after the war about 1921(Red Cross medal 3rd class 1898 in fine zinc, 2018).

The obverse of this medal (Pl. 6) features a Geneva cross and its arms surmounted by Prussian Royal Crowns, between the arms are found letters, top left "W" in top write "R" which is the initials of the name of the king "Wilhelm Rex" and on the bottom left "A" and in bottom right "V" which is the initials of the name of the queen "Auguste Viktoria", who was the inspirer of the foundation of this medal, because of her responsibility as the supreme protector of the clubs of the Red Cross, so she wanted to award all those who work for the clubs, even in peacetime(Red Cross medal 3rd class 1898 in fine zinc, 2018).

The obverse side features an Oak branch swinging around the left edge, and there is a German inscription "Fuer Verdienste Um Das Rothe Kreuz" which means "For Merit to the Red Cross".

The Egyptian Order of the Nile (Pl. 7).

This order was established by Sultan Hussein Kamel on $14^{\text {th }}$ April 1915 and amended by the sultan Fuad I Decree on 11August 1919(Gouvernement Egyptien, 1920), then when Egypt became a kingdom, it was amended by the Royal decree no.5 in 1923 of king Fuad I, who amended it again by the decree no. 49 in 1926 (رجب، 2013)

The order form the fifth class(Statskalenderns Redaktör ed.,1955) according to its ribbon( رجب، 2013) which indicates that it was awarded to those who render the country valuable services. The order takes the shape of a ten pointed rayed star of silver upon which rests another white enamel quincunx star of silver, in the center of which appears a protruding circular disc of silver on which is inscribed with blue enamel Arabic Mameluke Kufic inscription the word كم نعمة في مصر يُشنكر نيلها النيل أصل " the Nile" and around it in a circle is a verse inscribed" "النيل" which may be translated as "What Grace Egypt owes to the Nile, the Nile is the source of prosperity and blessings", which was written by the Calligrapher "Ahmed Youssef" in 1914, upon the request of Sultan Hussein Kamel who ordered using the Kufic Calligraphy in all the decoration and orders (يوسف، 1933). The signature of the designer "J.LATTES" of Cairo, was inscribed on the reverse. The braid is connected to the blue with yellow stripes ribbon by a clasp that takes a crown shape. the ribbon confirms the class of this order from the fifth Class (رجب، 2013). 
The Egyptian King Farouk's Wedding Badge (Pl. 8).

The badge of the first marriage of King Farouk with queen Farida that was gifted to the invited dignitaries to the royal wedding party (عبد الكريم،2016). It is considered one of the rarest artifacts in the collection of von Gerber that confirm, his presence in the royal wedding as a General consul of Sweden on $20^{\text {th }}$ March 1938.

The badge is made of gilded alloy which takes the shape of the Egyptian throne with the curtain that sheds the royal throne. In the place of the throne a layer of enamel with photographic image of the king Farouk and the queen Farida, was placed with the date of the wedding written

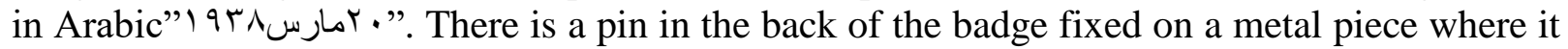
is inscribed the German maker's mark is inscribed in French and it says "PAULMANN\&CRONE LÜDENSCHEID ALLEMAGNE".

The Order of Merit of the Hungarian Republic (Pl. 9).

The Order of Merit of Hungary was officially instituted on June $19^{\text {th }} 1923$ as the Hungarian Cross of Merit, or "Magyar Érdemkereszt". It was not called the Hungarian Order of Merit until 1935 when the name was changed from the "Magyar Érdemkereszt" to the "Magyar Érdemrend", or Hungarian Order of Merit (Czink, 1999).

In February 1946, the first government of the Republic of Hungary was established under the patronage of the USSR, then the order of merit of the republic of Hungary, or "Magyar Köztársasági érdemrend" was founded on $14^{\text {th }}$ September 1946 , For the need to appreciate its citizens and foreigners. The order was granted in the period from $15^{\text {th }}$ January 1947 to $12^{\text {th }}$ October 1949 when it was abandoned by the communists who have acquired a great influence on the government and the society. (Bodrogi, Molnár and Zeidler, 2005)

The order from the Commander Class (Statskalenderns Redaktör ed., 1955) is taking the shape of a cross pattée of silver, covered with very good quality white enamel with red lines in the circuit. In the middle of the medallion, which is bordered by green enamel representing a wreath, there is a shield in a red enamel background. The shield has to have colored enamel with the Hungarian flag colors, but that was for military awarded only (Bodrogi, Molnár and Zeidler, 2005). The year of the foundation 1946 is inscribed on the reverse of the medallion,. This order to be worn as a necklace decoration hanging from a striped red, white and green ribbon with the colors of the Hungarian flag.

Pope Christopher II $40^{\text {th }}$ anniversary ordination commemorative medal ( $\left.\mathrm{Pl} .10\right)$.

This circular golden medal was gifted to the important dignitaries that invited to the celebration of the $40^{\text {th }}$ anniversary of the bishop ordination of Pope Christopher II, the patriarch of the Greek orthodox of Alexandria. Christopher II was a respected and compassionate man of the church and this medal is one of the rare things that related to him, especially that he did not leave any personal belongings(إفثيميوس،2008).

The obverse of the medal is featuring the winged lion symbol of saint Mark, which is in the middle of a circular line of Greek inscriptions that read" ХРІ $\Sigma$ ТОФОРО $\Sigma$ О В ПАПА $\Sigma$ КАI ПАTPIAPX $\Sigma$ A $\Lambda$ EAN $\triangle$ PIA $\Sigma$ 1948" which means "Christoforos II Pope and Patriarch Of Alexandria 1948", on the reverse side another Greek inscription rounded by a wreath that tell "1908.......... His Most Divine Beatitude Patriarch of Alexandria Christoforos II, the Commission of the Celebration $19^{\text {th }}$ December 1948". 
Pope Christopher II 50 ${ }^{\text {th }}$ anniversary ordination commemorative medal ( $\left.\mathrm{Pl} .11\right)$.

This circular golden medal was presented to the important dignitaries who were invited to the celebration of the 50th anniversary of the bishop ordination of Pope Christopher II, the patriarch of the Greek orthodox of Alexandria. The obverse side featuring Greek inscriptions rounded by two branches of olive, its translation is "Commemorative Festival of Golden Jubilee Priest and Patriarch Christopher II 1908-1958". The reverse side features Greek inscription "Z $\Omega H N$ HTH $\Sigma$ ATO $\Sigma$ E KAI E $\Delta \Omega$ KA $\Sigma$ AYT $\Omega$ MAKPOTHTA HMEP $\Omega N$ ( $\Psi \alpha \lambda \mu$ oí $\mathrm{K}$ ! 5)", which means "He asked life of thee: and thou hast given him length of days (Psalm 20:5)" under two crossed palm branches.

The order of the White Rose of Finland (Pl. 12).

The order of the White Rose is one of the official orders in Finland that was ratified by General of the Cavalry, later Marshal of Finland, Baron Gustafe Mannerheim on $16^{\text {th }}$ May 1919. the order is to be conferred upon the Finnish and foreign who have distinguished themselves in the service of Finland, the motto of the order is "For the Good of the Fatherland" (Karumaa, 2017). It was designed by the Finnish artist Akseli Gallen-Kallela (1865-1931), who designed it in the shape of white enamel cross pattée, with less curvature, with silver lions of Finland between the arms, with loop for ribbon suspension; the face with a blue circular central medallion within a gilt ring bearing a white and gold stylized rose petal pointing downwards which is considered of the earliest vintage. According to its material and shape and the color of the ribbon, this order is of the class of Knight (Karumaa, 2017), not a first class knight as was confirmed by other resources (Statskalenderns Redaktör ed., 1955).

The order of the Lion of Finland (Pl. 13).

The order of the Lion is one of the official orders in Finland, which was founded by a decree (747/1942) of the president of the republic of Finland Risto Rayti, issued on 11 September 1942, during WWII. According to the decree the order is to be awarded in recognition of outstanding civilian or military merit and may be conferred upon Finnish or foreign(Karumaa, 2017).

It was designed by Oskar Pihl, who was a chief designer at Alexander Tillander Jewelers and Goldsmiths in Helsinki (Karumaa, 2017). This order is of the class of Commander of Class (Von Gerber, 1954; Statskalenderns Redaktör ed., 1955) and it is taking the shape of white enameled cross pattée, with less curvature, with the lion of Finland placed at the center of the cross is a raised red roundel surrounded by a stylized wreath. the ribbon color is red, which is the same color of the Finish national coat of arm .

The order of the Great Cross of Saint Mark the Apostle (Pl. 14).

The Patriarch of the Greek orthodox of Alexandria and All Africa award the Saint Mark's Great Cross to those whom wants to present his appreciation and to the diplomats in Alexandria especially at the end of their service in the city and this tradition continues till now (The Greek orthodox Patriarchate of Alexandria, 2017).

The order takes the shape of Latin cross pattée with silver-gilt-edges with turquoise color enamel panels on the arms, with ornate decoration between the arms and with patriarchal Mitre suspension. In the middle of the obverse side there is a circular central pale blue enamel medallion bearing the gilt winged lion of Saint Mark passant within a black enamel ring inscribed in gilt letters 'ЕY $\Lambda$ ОГІА АПОСТО $\Lambda$ O MАРКОY - A $\Xi X$ ' which means "Blessed Apostle Mark"; the ribbon adorned with a rosette added to distinguish the first knight class. 
The Egyptian Order of Merit (Pls.15-16).

This order was created by law no. 528 in 1953 and it is presented by the president of the republic to the Egyptians and others who render the country valuable services, and includes five classes. the one here is from the second class, Its braid takes the form of a quincunx star of oxidized silver upon which rests another quincunx star of gold and silver in the center of which appears a circular disc of gold on which is inscribed the word Merit in Arabic (الاستحقاق). The order is similar to the braid, but smaller in size. It is connected to the cordon by a blue clasp on which a vulture spreading its wings up high is shown. The braid is to be worn on the right side of the chest and C.W. von Gerber was granted another braid to be attached to the neck of the same color as the cordon(Cabinet of the Grand Chamberlain department, n.d.).

This order famous for other names as order of the independence or the order of Guides as it was awarded to the ship guides of Suez canal for their efforts and success in preserving the continuity of ship sailing in the Suez canal after the nationalization Crisis when the majority of the foreign guides left the work so as a pressure on the political leadership of Egypt(اللقاني،2005).

Von Gerber was delighted when he received the order of Merit. This was obvious in the letter he sent to his brother Tage on $14^{\text {th }}$ August 1959, shoeing his happiness to add one more order to his orders, he said "I have recently received a valuable addition to my orders from President Gammal Abdel Nasser, who awarded me the order of Merit 2nd class (Grand Officer)" and he was thinking taking a picture wearing the official uniform with the new order, but it was in the summer, so he left the picture to the next season, which unfortunately never saw. in the same letter he predicted his death by saying "here is seldom the occasion to bear such awards, but I would like to take a photo for remembrance, probably my last, but first from autumn, for the time being. At $30^{\circ}$ and humidity, it is no pleasure to wear the uniform. Such a photo might be introduced in the next edition of the calendar" (The Archive of Swedish Institute).

\section{Dress Miniatures: Mounted Group of seven (P1. 17).}

In a red small box of F. Godet and John of Berlin, there is a mounted group of seven miniatures which represent reduced size edition of the full-size orders of von Gerber, hanged in a strip starting with a pin and ends with a gilt button with "Godet Berlin" inscribed on its face. Those miniatures are for three orders of what was previously mentioned: that of the PrussianGermany Red Cross Medal, the Egyptian order of the Nile and the Finnish order of the White Rose. The other four miniatures were not found between the collection preserved by SwedAlex, but it appears in the painting of von Gerber in the official-suit demonstrated in the institute on the second floor (Pl.no. 1). The four miniatures are:

\section{The miniature of the Danish Order of the Dannebrog}

This order was instituted by Christian V in 1671. According to the statutes of the order that was written in 1693, the "White Knight" was the only class of this order, which corresponds to today's "Grand Cross Knight". Worth mentioning that it was believed that the origin of this order is that of Valdemar the Victorious for the Battle of Lyndanisse on $15^{\text {th }}$ June 1219 . the order was limited award to Danish royalty and noblemen, but the king Frederik VI expanded the order in 1808 when the order was divided into four Degrees (The Royal Orders of Chivalry, 2018); Von Gerber was awarded the fourth degree: the knight class (Von Gerber, 1954; Statskalenderns Redaktör ed., 1955).

The miniature takes the shape of the cross pattée, with white enamel arms with red edges and Danish crowns connecting the arms with loop for ribbon suspension connected to the cross by a crowned 'FVI' for King Frederik VI. It is also written on the reverse side on the upper arm of 
the Cross. Meanwhile the years of the institution and amendments of the order are written on the other arms; 1219 on the right arm, 1671 on the left one and 1808 on the lower one. In the middle a crowned "W" for the King Valdemar is shown. The obverse side is a kingdom motto "GUD" on the left arm, "OG" on the upper arm and the word "KONGEN" divided in two parts, "KON" on the right arm and "GEN" on the lower one, all three words mean "God and the King". 'C5' is shown in the middle representing King Christian V.

\section{The miniature of the Swedish Order of Vasa}

The order was founded on $26^{\text {th }}$ May 1776 by King Gustavus III on the day of his coronation and expired in 1975 (Braunsteinm, 2006). The order was to be rewarded to all those who render important services to his nation, by their writings or by practical improvements in the fields of agriculture, mining or commerce. It was divided into three classes (Tagore, 1884; LawranceArcher, 1887); von Gerber was awarded the second category, the so-called "commander class" (Von Gerber, 1954; Statskalenderns Redaktör ed., 1955). This order was worn by a green board ribbon around the neck (Tagore, 1884).

It is a white enameled Maltese cross, with crowns between arms that has globules at the points, in the middle a escutcheon contains the vasa crest surrounded by a red enameled stripe with golden edges and with the legend "Gustaf den Tredie instiktare MDCCLXXII" which means "Gustavus III, instituted 1772" which commemorates the charge on the shield of Gustavus Vasa and to be suspended from a loop connected to the cross by a crown. (Tagore, 1884; LawranceArcher, 1887)

\section{The miniature of the Swedish order of the Polar Star.}

This order is the third highest order in the Swedish kingdom, King Fredrick I founded the order of the polar star on $28^{\text {th }}$ April 1748, which was conferred for civil merits and virtues, for zeal in the promotion of public good and useful institutions civilian or foreigner, the order had three classes, (Tagore, 1884; Lawrance-Archer, 1887) the lowest one was awarded to von Gerber, the knight Class"(Von Gerber, 1954; Statskalenderns Redaktör ed., 1955).

The miniature is an enameled white Maltese cross with globules at the points, with crown between the arms. In the center there is a blue enameled circular medallion with legend "Nescit occasum", which means " It knows no decline". The cross is connected with the loop by a crown, to be suspended from a black ribbon that was famous with till that order was used to be called the order of the black ribbon till the ribbon color changed in 1975(Braunsteinm, 2006).

The miniature of commemorative medal of the Swedish King Gustav V's 70th Birthday.

This miniature for the medal that was established on $25^{\text {th }}$ May 1928 for the Kings $70^{\text {th }}$ birthday on $16^{\text {th }}$ June 1928 , which was awarded to all who participated in the celebration and one of those was von Gerber "(Von Gerber, 1954; Statskalenderns Redaktör ed., 1955). It is a pale blue enameled escutcheon under a crown of the Gustavian type. The middle part has the mirrored King monogram of gold, surrounded by an oval white rim containing a legend "1858 16 JUNI 1928"on a white background near the edge.

\section{Discussion}

It is worth discussing these interesting facts revealed by the results of the documentation of eight commemorative medals from Egypt and Sweden, in addition to two medals of honor from Prussia that related to sport, religious and diplomatic fields. Besides nine orders and decorations from Egypt, Sweden, Finland, Denmark, Hungary and the Greek orthodox 
patriarch that related to the political, diplomatic and economic fields. Additionally, an Egyptian royal wedding badge.

Based on the biography of von Gerber and the documentation of the collection, the importance of the collection raised by the importance of the person to whom it is related. Von Gerber was a very successful man on many fields, nationally and internationally. he was a brilliant businessman during his carrier for more than 40 years and moreover, he was so active in the social and cultural life.

From the collection, the researcher could deduce that von Gerber was living in Egypt before 1907 but without a decision to be a resident until he took this decision in 1907. so this due to the two rare and valuable commemorative medals of the Egyptian Trotter from years 1905 and 1906, which confirms the tied relationships he made in Egypt by commerce, notably being one of the dignitaries who was awarded these medals. Also being awarded two successive medal reflects his importance as a dignitary not as tourist or a guest.

This busy life never took him from being an important person in his homeland. So, the commemorative medal of the Olympic games of Stockholm that he was awarded, reflects how he was so influential to be honored and awarded this medal, although he was out of Sweden, with no political title till then.

According to the rare sources that spoke about his life, no one of those referred to his important role during WWI. This was proven by two Prussian medals he was awarded with, which reflects his role in Egypt during this time. There is a great possibility that the he took good care of the Prussian people and business in, so the role of von Gerber during this war needs more study but through the German sources as no documents helped in finding that in SwedAlex archive.

The order of the Nile is considered one of the highest orders he was awarded with and from the unique pieces in his collection is the miniature of this order, which is not shown in any museum in Egypt. From the order's box the researcher read the title of Fuad I when he was a sultan, which means that he was awarded this order in the period between 1917 and 1922. This suggests the possibility that he was awarded in 1921 when he was appointed as a vice-consul in Alexandria.

King Farouk's royal wedding badge shows that von Gerber was a very well representative of his country as a Consul to be invited to the royal wedding. Because of that, he was promoted in the next year to a General Consul and this promotion was related to be awarded two of the three highest orders of Sweden; the order of Vasa and the order of the polar star. In addition to that he was one of the dignitaries who were invited in the ceremony of the $70^{\text {th }}$ anniversary of the birth of the Swedish king Gustav V and being awarded the rare medal of this event, after being a consul for three years only.

Uniquely, enough a person with this variety of orders awarded from of different countries could be possibly explained by the great role he played during WWII, when he took care of their people and business, as an illustration of his success in WWI that let all of these countries, put its trust in him during WWII. More importantly, referring to his diplomacy that helped him having the courage in front of the British forces.

Regardless of being a protestant follower, von Gerber established a school for Sight impaired girls that served more 22 girls, between seven and ten years old, to teach them Koran by three imams from Abu Al-Abas mosque that is according to Mrs. 'Aidah Hasan Sobh, the daughter of von Gerber's agent, who was living in the same mansion on a floor devoted to them. Meanwhile he was awarded a medal of the Greek orthodox pope Christopher II $40^{\text {th }}$ 
anniversary of ordination, which reflects his good relationship with the largest community in Alexandria,

What reflects his respect in the Alexandrian society is being awarded the commemorative medal of the $50^{\text {th }}$ anniversary of the same pope, but this time when von Gerber was not the general consul anymore, which emphasizes that he was being awarded in the past not because of his political position but for his deeds as a respected person in the city.

Accordingly, the discussion proved the historical importance of the collocation and revealed new historical information about the city and the impact of von Gerber in Alexandria. Besides, proving the importance of letting this collection being accessible for everyone in a museum to promote the heritage of the city.

\section{Conclusion}

The results shows consistency with the targets of the study, by providing evidence of the importance of the collection of von Gerber, to encourage the establishment of a private museum in SwedAlex based on the documented medals and orders that were studied in this paper.

Moreover, studying the collection for the first time, revealed new information about Alexandria and the role of the diplomats during the first mid of the Twentieth Century. Future studies could fruitfully shed more light on the history of Alexandria during that period.

At the end, the collection of C.W, von Gerber represents unknown history that has to be revealed to spread the knowledge and raise the awareness for our heritage in Alexandria. Especially that SwedAlex opens its doors in all the cultural events of Alexandria and receive visits from anyone interested in heritage, so it is important to the tour guides to know about von Gerber and his collection, as the institute hire Tour guides for its foreigner visitors.

\section{Arabic Bibliography}

$$
\begin{aligned}
& \text { ابراهيم، سمية (1998) "النياشين والاوسمة في أسرة محمد علي من مجموعة متحف الفن الإسلامي"، مجلة مركز الدراسات }
\end{aligned}
$$

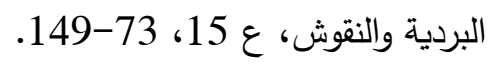

$$
\begin{aligned}
& \text { رجب، سارة (2013) النياشين والأوسمة في مصر في عهد اسرة محمد علي، رسالة ماجستير، كلية السياحة والفنادق، } \\
& \text { جامعة الإسكندرية. } \\
& \text { سولويانيس،إفثيموس (2008) اليونانيون بمصر في العصر الحديث، ترجمة سبيروس كملاكيس، رابطة الصداقة اليونانية } \\
& \text { المصرية، أثينا. } \\
& \text { عبد الكريم، لوتس (2016) فريدة التاج والفن، الدار المصرية اللبنانية، القاهرة. } \\
& \text { اللقاني، سامح (2015) موسوعة القلائد والنياشين والاوسمة والأنواط والميداليات المصرية، د.ن، الإسكندرية. } \\
& \text { يوسف، أحمد (1933) الخط الكوفي، مطبعة حجازي، القاهرة. }
\end{aligned}
$$

\section{English Bibliography}

Berenes, E.M. (1886), "the myths and legends of ancient Greece and Rome", Clark and Maynard, New York.

Bergvall, Erik ed. (1913), "The fifth Olympiad: the official report of the Olympic Games of Stockholm 1912", Wahlström \& Widstrand i distr., Stockholm.

Bodrogi, Peter, Molnár, József, and Zeidler, Sándor, (2005) "Nagy magyar kitüntetéskönyv: A magyar állam rendjelei és kitüntetései”, Rubicon House, Budapest. 
Braunsteinm, Christian (2006), " Utmärkelsetecken på militära uniformer =Decorations on Swedish military uniforms", Christian von Arbin, n.p. available online: http://www.sfhm.se/contentassets/84a6e4f1b2ce4e2b96c4ba578a41c503/sfhm-skriftserieutmarkelsetecken-pa-militara-uniformer-christian-braunstein-2007.pdf (accessed 02/08/2018)

Burling, Ingeborg ed. (1956) "Vem Är Det : Svensk Biografisk Handbook1957", PA Norstedt \&Søners Publisher, Stockholm.

Collection of Adolphe rivet (2018), the Metropolitan Museum of Art, available from: https://www.metmuseum.org/art/collection/search\#!/search?artist=Rivet\%20Adolphe \$A dolphe\%20Rivet (accessed 30/01/2018).

Czink, Peter (1999) "The Hungarian Cross of Merit and the Hungarian Order of Merit" Magyar Front, Nov. Dec. edition.

El-Abbadi, Mostafa ed.(2003) "the Archaeological society of Alexandria in one hundred and ten years", the Archaeological society of Alexandria, Alexandria.

Gjerstad, Einar, Lindros, John, Sjoqvist, Erik \& Westholm, Alfred (1934),"the Swedish Cyprus Expedition finds and results of the excavations in Cyprus 1927-1931", vol.1, the Swedish Cyprus Expedition, Stockholm.

Gouvernement Egyptien (1920),"Grades et Décorations institues par sa Hautesse Le Sultan", Imprimerie Nationale, Cairo.

Hjarre, Leif and Signeul, Jan, (n.d.) "Carl Wilhelm von Gerber om hans live och dod", Archive of the Swedish institute in Alexandria.

International Council on Archives (1981), "Sources Of the history of north Africa, Asia and Oceania in Finland, Norway, Sweden", De Gruyter Saur, Munich.

Karumaa, Antero (2017) "A guide to the orders and decorations of Finland", Edita publishing Ltd., Helsinki.

L'Annuaire Égyptien et l'Indicateur Égyptien (1913), 27e année", a Société Anonyme Égyptienne de Publicité, Le Caire.

L'Annuaire Égyptien et l'Indicateur Égyptien (1941), 55e année", a Société Anonyme Égyptienne de Publicité, Le Caire.

Lawrence-Archer, James (1887), "The orders of chivalry: From the original statutes of the various orders of knighthood, and other sources of information", W. H. Allen and co., London.

Louis Auguste Albert Erdmann (2006), Musée d'Orsay, available from:

http://www.musee-orsay.fr/en/espace-professionnels/professionals/researchers/rech-rec-arthome/notice-artiste.html?no_cache $=1 \&$ nnumid $=11923 \&$ retouroeuvre $=\% 252 \mathrm{Fes} \% 252$ Fcolecciones\%252Fcatalogo-de-obras\%252Fnotice.html\%253Fno_cache\%253 D1\%2526nnumid\%253D053238\%2526cHash\%253D6c49f6ddd8\&cHash=08cad565c5 (accessed 30/01/2018).

"News of Scandinavia"(1908), The Princeton Union newspaper, 25 June.

Noran, Alexander (n.d), "Adolphe Rivet; A Man through Medals" in Poland coin Grading services web site, available from:

http://pcgmgrading.com/adolphe-rivet-a-man-through-medals/ (last accessed 30/1/2018).

Red Cross medal 3rd class 1898 in bronze (2018), Ehrenzeichen-Orden available from:

http://www.ehrenzeichen-orden.de/deutsche-staaten/rote-kreuz-medaille-3-klasse-1898-inbronze.html (accessed 30/01/2018).

Red Cross medal 3rd class 1898 in fine zinc (2018), Ehrenzeichen-Orden available from: http://www.ehrenzeichen-orden.de/deutsche-staaten/rote-kreuz-medaille-3-klasse-1898-infeinzink.html (accessed 30/01/2018). 
International Journal of Heritage, Tourism and Hospitality Vol. (11), No. (4), October, 2017

By: Faculty of Tourism and Hotels, Fayoum University

A Special Issue on 'Entrepreneurship of Tourism, Hospitality and Heritage in Egypt': A Vision for Sustainable Development'

The $1^{\text {st }}$ International Conference Organized by Faculty of Tourism and Hotel Management, Pharos University,

Alexandria, Egypt on $24^{\text {th }}-27^{\text {th }}$ October 2017

Registration No .: 97182 (2017)The IVV1-Humanities of the WWU Münste library, available from: https://www4.ivv1.uni-muenster.de/litw3/Aegyptologie/1_standard_kurzanzeige autfr.php?schlagwort=Gerber,\%20C.W.\%20de (accessed 30/01/2018)

Statskalenderns Redaktör ed. (1955), "Sveriges statskalender för året 1955” (1955), Almqvist and Wiksell, Uppsala.

Tagore, Sourindro (1884), "The Orders of Kinghthood", Vol. II, Bose and Co., Calcutta.

The Archive of Swedish Institute of Alexandria.

The Greek orthodox Patriarchate of Alexandria (2017), available from: http://www.patriarchateofalexandria.com/index.php?module=news\&action=details\&id= 1339\#prettyPhoto (accessed 30/01/2018).

The Royal Orders of Chivalry, (2018), the Official Danish Monarchy, available from:http://kongehuset.dk/en/the-monarchy-in-denmark/the-royal-symbols/the-royalorders-of-chivalry (accessed 30/01/2018).

Von Gerber, Carl (1944) "Une visite à Alexandrie en 1829 : extrait du Bulletin de la société Royale d'archéologie d'Alexandrie no.36», société de publications Egyptiennes, Alexandrie.

Von Gerber, Tage (1954), "Ätten von Gerber sedan medeltiden", Vol.1, n.p.

125-years-of-primus n.d. Primus available from: http://www.primus.eu/our-story-191/125years-of-primus (accessed 30/01/2018) 
International Journal of Heritage, Tourism and Hospitality Vol. (11), No. (4), October, 2017

By: Faculty of Tourism and Hotels, Fayoum University

A Special Issue on 'Entrepreneurship of Tourism, Hospitality and Heritage in Egypt': A Vision for Sustainable Development'

The $1^{\text {st }}$ International Conference Organized by Faculty of Tourism and Hotel Management, Pharos University,

Alexandria, Egypt on $24^{\text {th }}-27^{\text {th }}$ October 2017

\section{The plates}

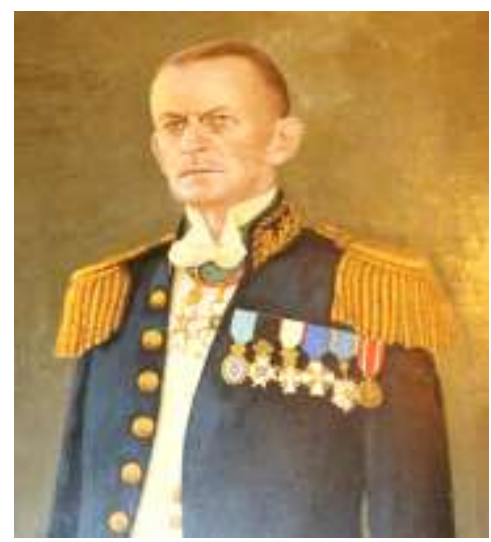

Plate 1: the official portrait of C. W. von Gerber wearing his orders and medals (taken by researcher)

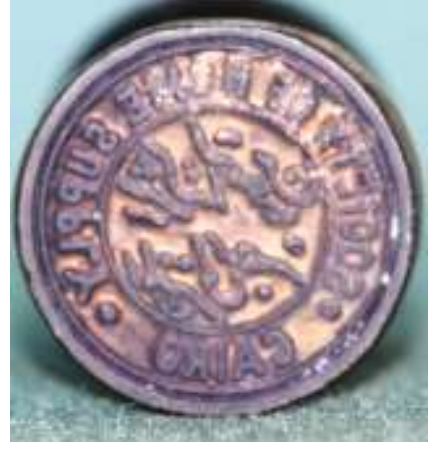

Plate 2: the stamp of the Society of Home Supply in Cairo (taken by researcher)

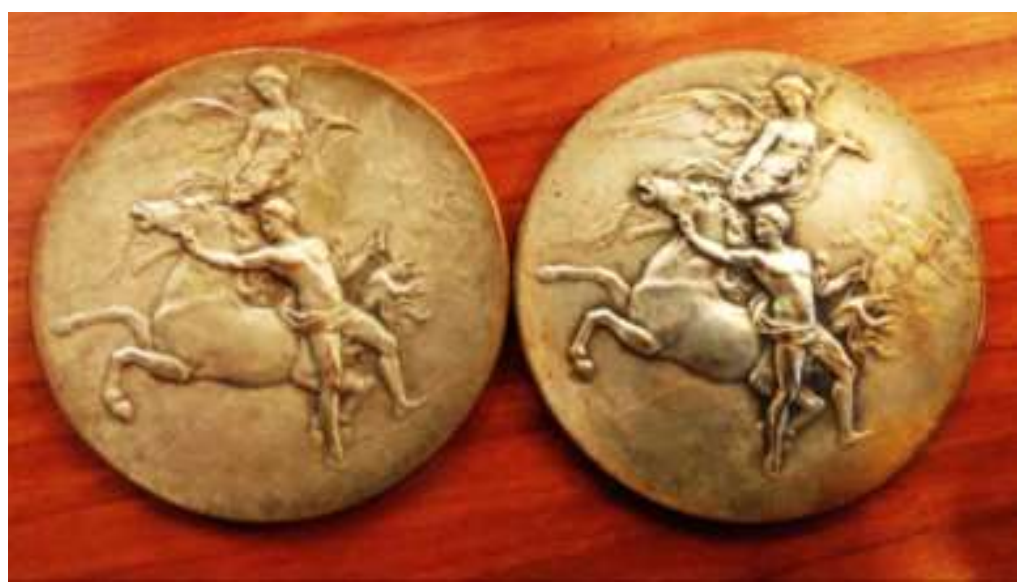

Plate 3: the obverse side -Two Commemorative Medals of the Egyptian Trotter. (taken by researcher)

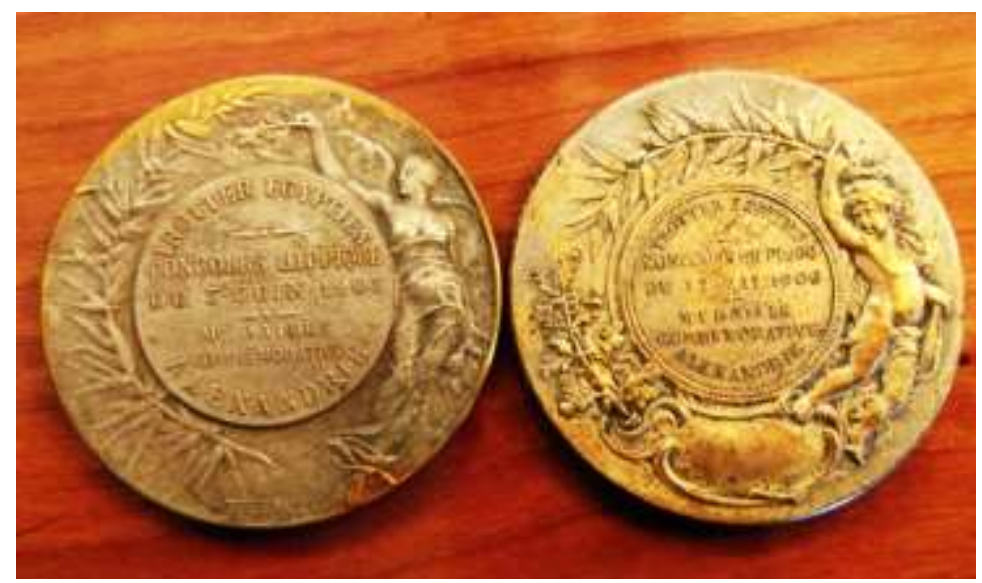

Plate 4: the reverse side -Two Commemorative Medals of the Egyptian Trotter (taken by researcher) 
International Journal of Heritage, Tourism and Hospitality Vol. (11), No. (4), October, 2017

By: Faculty of Tourism and Hotels, Fayoum University

A Special Issue on 'Entrepreneurship of Tourism, Hospitality and Heritage in Egypt': A Vision for Sustainable Development'

The $1^{\text {st }}$ International Conference Organized by Faculty of Tourism and Hotel Management, Pharos University, Alexandria, Egypt on $24^{\text {th }}-27^{\text {th }}$ October 2017

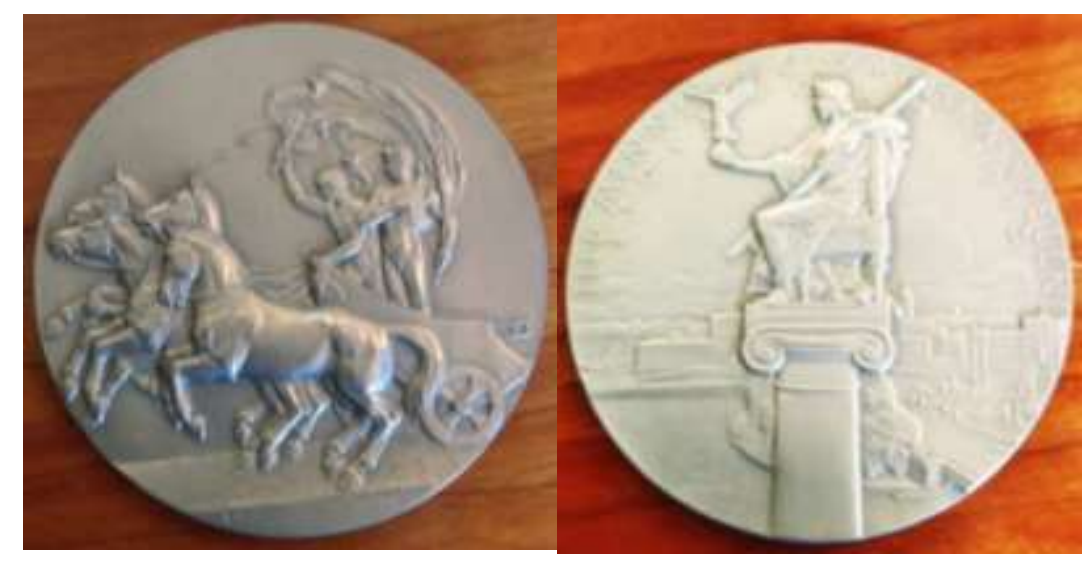

Plate 5: Commemorative medal of the Stockholm Olympic Games. (taken by researcher)
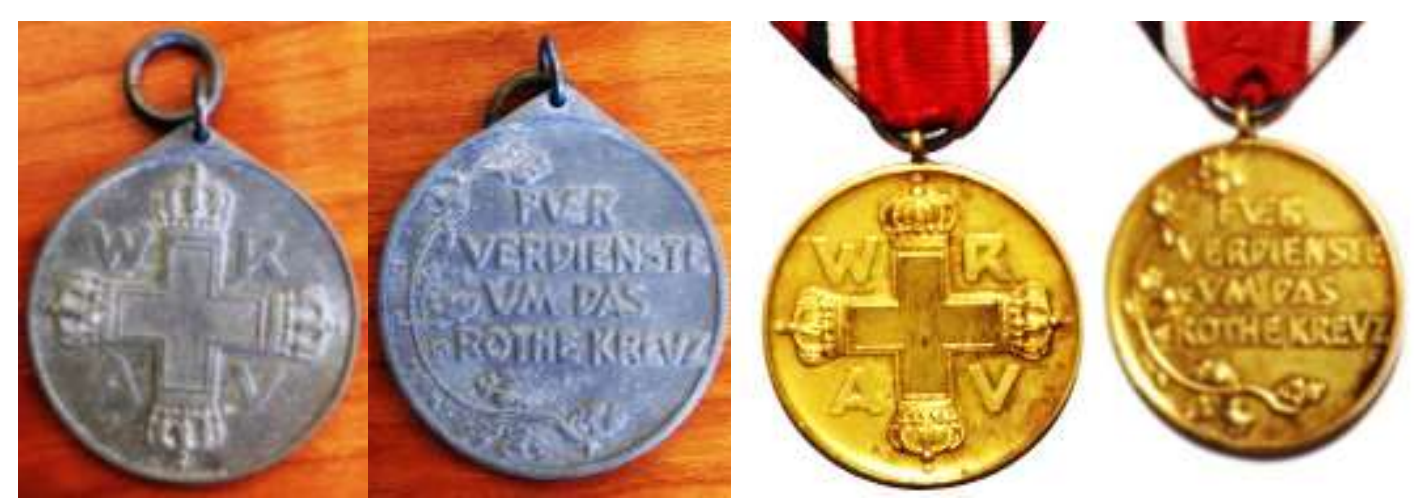

Plate 6: Two Prussian Red Cross Medals

(taken by researcher)

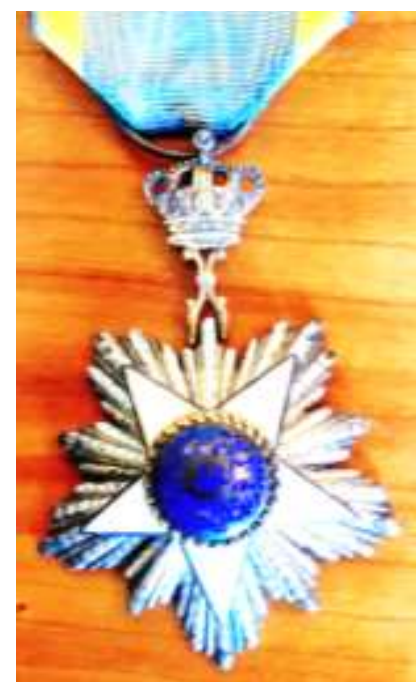

Plate 7: The Egyptian Order of the Nile(taken by researcher)

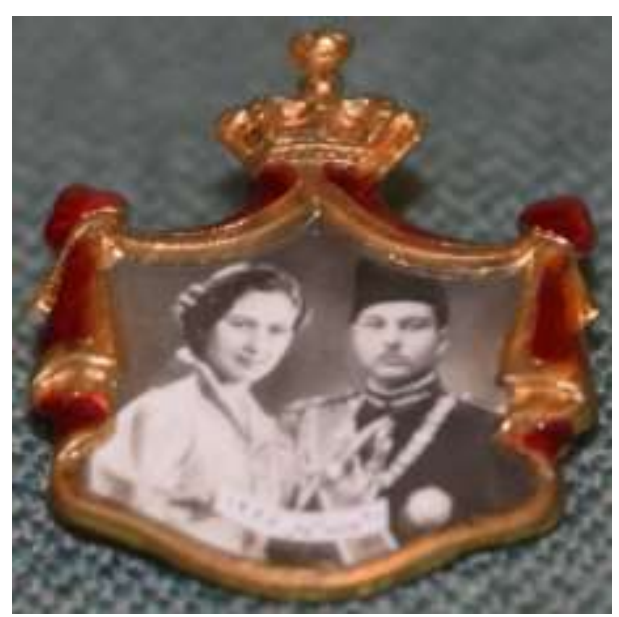

Plate 8: The Egyptian King Farouk's Wedding Badge (taken by researcher) 
International Journal of Heritage, Tourism and Hospitality Vol. (11), No. (4), October, 2017

By: Faculty of Tourism and Hotels, Fayoum University

A Special Issue on 'Entrepreneurship of Tourism, Hospitality and Heritage in Egypt': A Vision for Sustainable Development' The $1^{\text {st }}$ International Conference Organized by Faculty of Tourism and Hotel Management, Pharos University, Alexandria, Egypt on $24^{\text {th }}-27^{\text {th }}$ October 2017

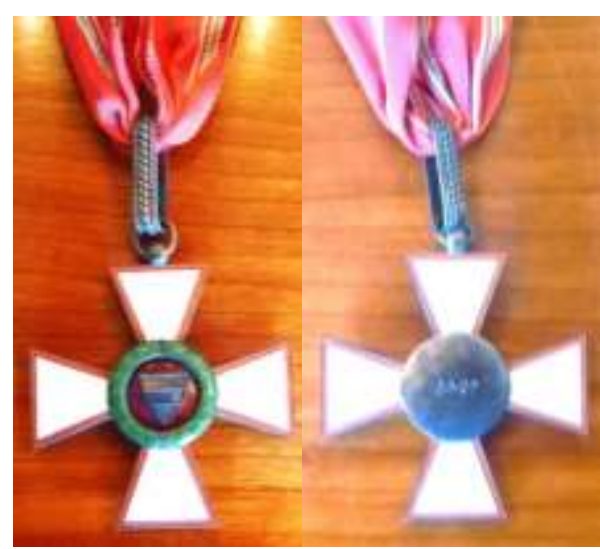

Plate 9: The Order of Merit of the Hungarian Republic (taken by
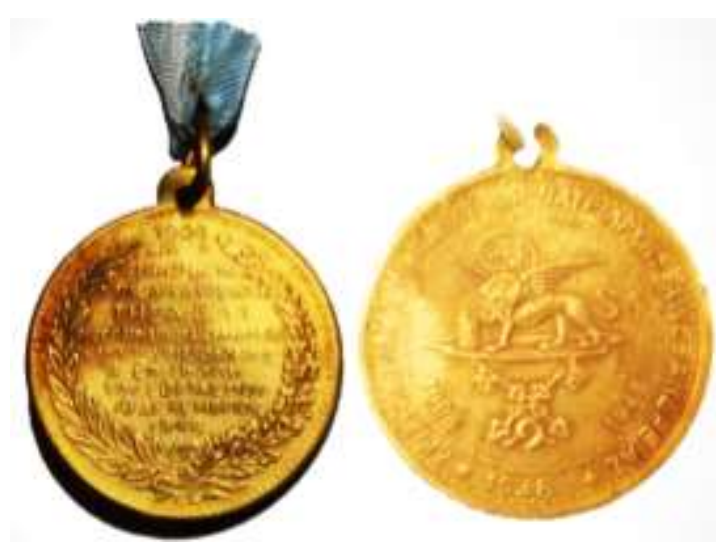

Plate 10: Pope Christopher II $40^{\text {th }}$ anniversary ordination commemorative medal (taken by

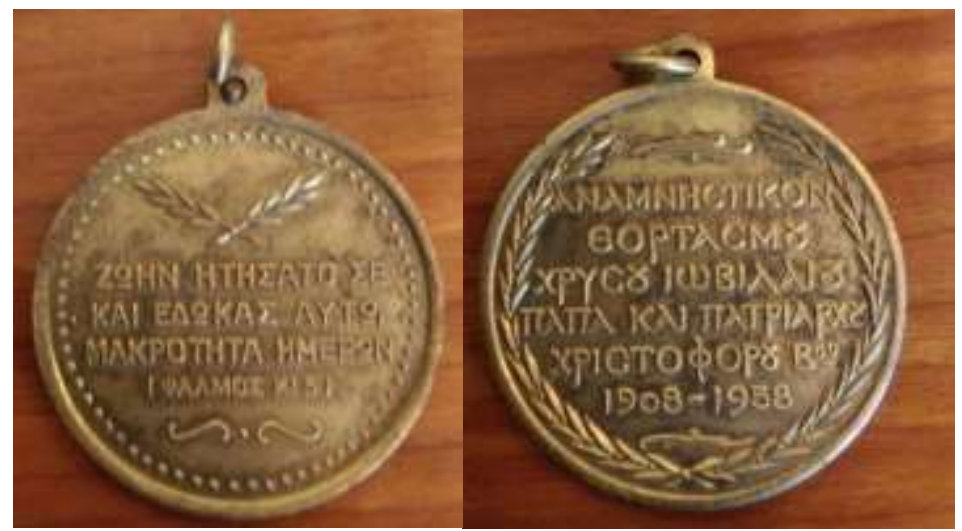

Plate 11: Pope Christopher II 50th anniversary ordination commemorative medal (taken by researcher)

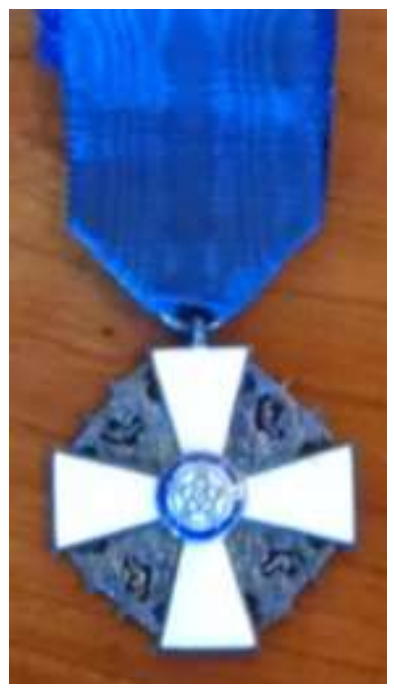

Plate 12: The order of the

White Rose of Finland(taken by researcher)

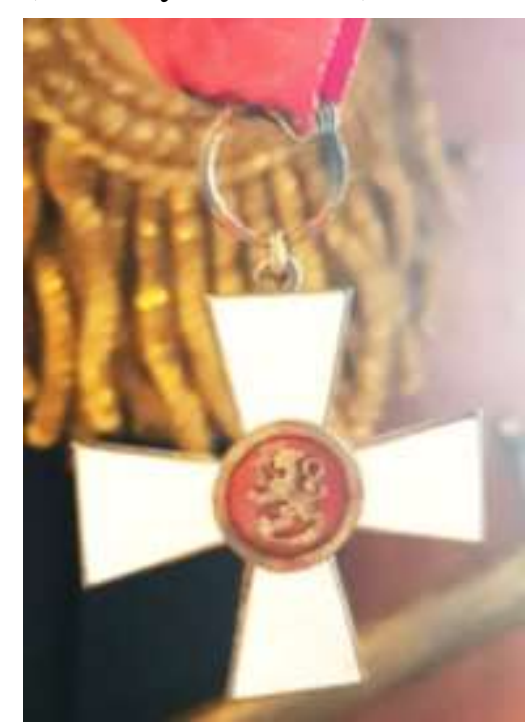

Plate 13: The order of the Lion of Finland (taken by researcher) 
International Journal of Heritage, Tourism and Hospitality Vol. (11), No. (4), October, 2017

By: Faculty of Tourism and Hotels, Fayoum University

A Special Issue on 'Entrepreneurship of Tourism, Hospitality and Heritage in Egypt': A Vision for Sustainable Development'

The $1^{\text {st }}$ International Conference Organized by Faculty of Tourism and Hotel Management, Pharos University, Alexandria, Egypt on $24^{\text {th }}-27^{\text {th }}$ October 2017

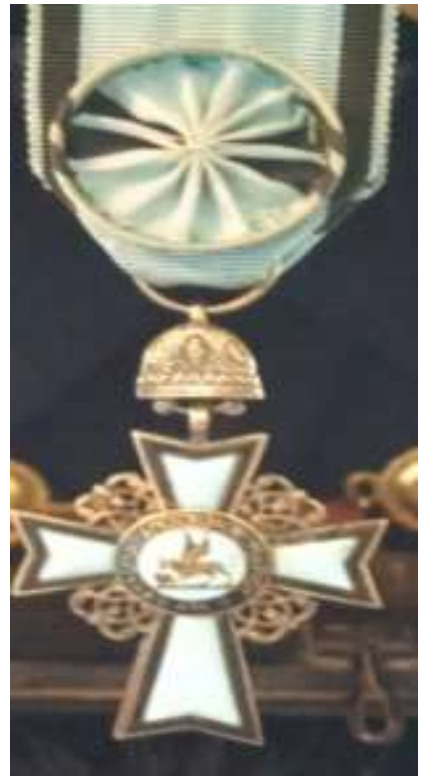

Plate 14: The order of the Great Cross of Saint Mark the Apostle(taken by researcher)

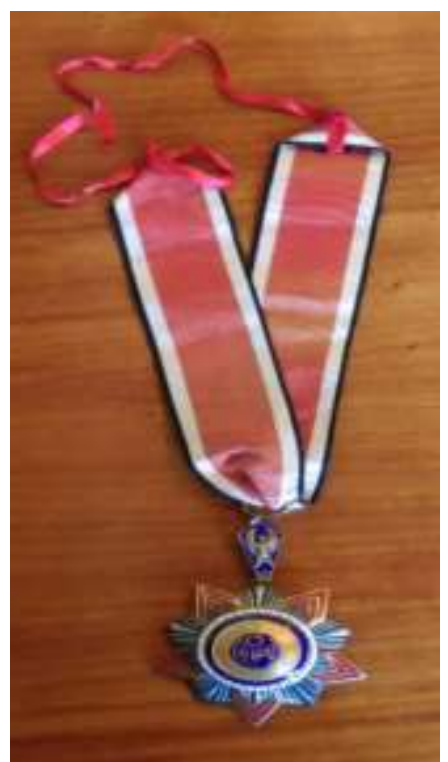

Plate 15: The braid of Egyptian Order of Merit (taken by researcher)

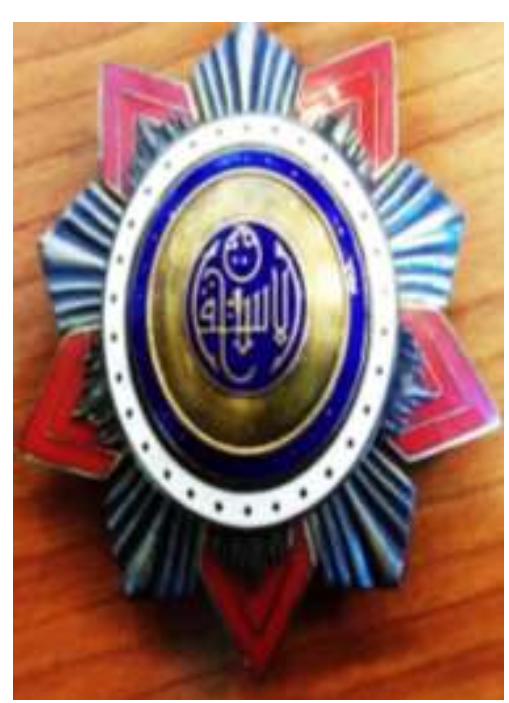

Plate 16: The Egyptian

Order of Merit

(taken by researcher)

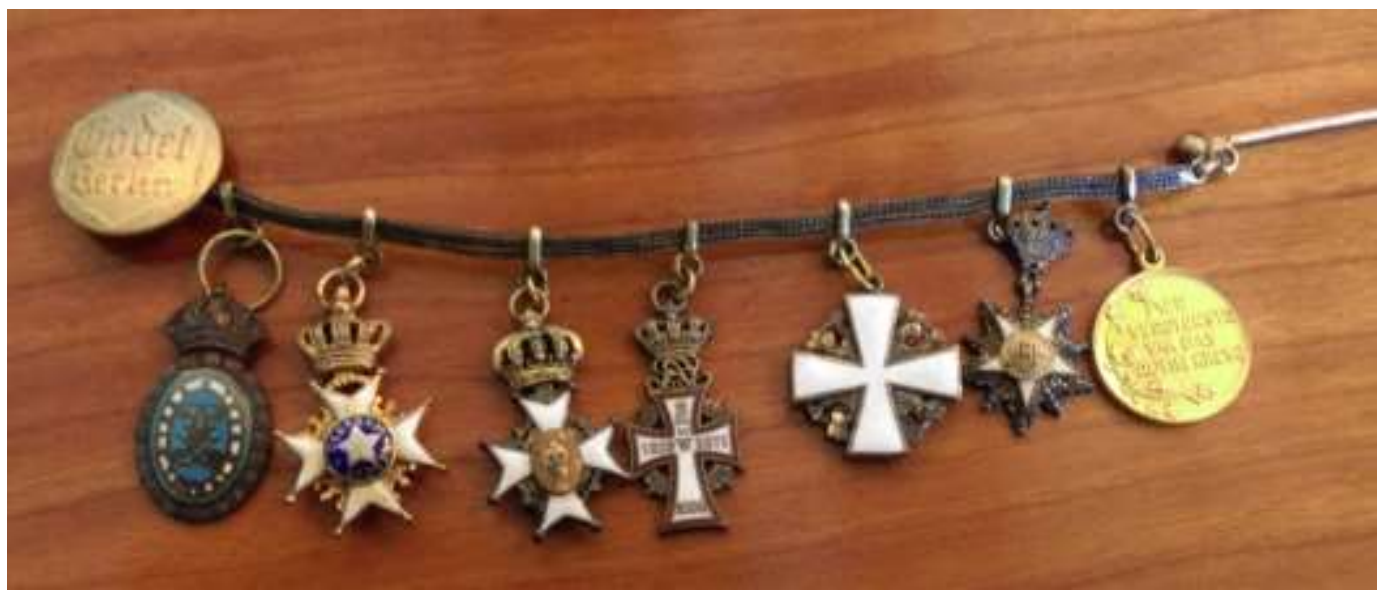

Plate 17: Dress Miniatures: Mounted Group of seven, from the right 1- the Prussian Red Cross. 2- The Egyptian order of the Nile. 3- The order of the White Rose of Finland. 4- The Danish order of Dannegbrog. 5- The Swedish order of Vasa. 6- The Swedish Order of the Polar Star. 7- The commemorative medal of the Swedish King Gustav V's 70th Birthday. (taken by researcher) 